\title{
Factors influencing the Use of E-wallets and its Limitations
}

\author{
Shilpa Vasant Bhide \\ Assistant Professor, Department of Management Sciences, \\ Savitribai Phule Pune University, Pune, Maharashtra, India.
}

CITATION: Bhide, Shilpa Vasant (2019), "Factors influencing the Use of E-wallets and its Limitations", MERC Global's International Journal of Management, Vol. 7, Issue 3, pp. 222-227.

ARTICLE HISTORY: Submitted: February 16, 2019, Revision received: March 30, 2019, Accepted: April 12, 2019

ARTICLE TYPE: Research paper

\begin{abstract}
The technological advancement has made the transactions faster, cashless, but it must be noted that there are risks associated with the use of E-wallets and mobile wallets. The current paper tries to evaluate the use of electronic wallets. It studies the factors influencing the usage of E-wallets, the purpose of its use and the obstacles or the limitation in the use of E-wallets. A survey of 182 respondents was made. Chi square test was used for the hypothesis testing and for the purpose of further analysis multiple response analysis was used. E-wallets are believed a Useful mode of Payment. E-wallets transactions are secure. The respondents agreed to the statement believed that it is not necessary to carry cash. On the other hand, the respondents who disagreed, believed that the transactions are not secured as the risk associated with technology are also associated with the use of E-wallets. E-wallets promote cashless payments. In the ranking of the purpose of using E-wallets, Online shopping is the highest of all the other options given, the second rank is for bill payment followed by food delivery, followed by travel booking and retail transactions at the local shops. As far as the obstacles or limitation of use of E-wallets is concerned, $24 \%$ believed that there is a risk of money being lost, followed by $23.1 \%$ who worry about the security of payment, and $22.3 \%$ do not think there is any obstacle or limitation in the use of E-wallets. The respondent believed that offers $(25 \%)$, followed by ease of use at (24.8\%) are the important factors influencing the use of E-wallets.
\end{abstract}

KEYWORDS: E-wallets, Uses, Multiple response analysis.

\section{REFERENCES}

1. Bagla, Ramesh Kumar and Sancheti, Vivek (2018), "Gaps in customer satisfaction with digital wallets: a challenge for sustainability", Journal of Management Development, Vol. 37 Issue 6, pp. 442-451.I

2. Chandra, Y. U.; Ernawaty and Suryanto. (2017), Bank vs telecommunication E-Wallet: System analysis, purchase, and payment method of GO-mobile CIMB Niaga and T-Cash Telkomsel, 2017 International Conference on Information Management and Technology, available at: doi:10.1109/icimtech.2017.8273531

3. Gupta, Agrata and Xia, Chun (2018), A Paradigm Shift in Banking: Unfolding Asia's FinTech Adventures, in (ed.) Banking and Finance Issues in Emerging Markets (International Symposia in Economic Theory and Econometrics, Volume 25) Emerald Publishing Limited, pp. 215 - 254

4. Kreft, H. and Adi, W. (2008), Wallet Based E-Cash System for Secured Multi-hop Cash Exchange, $3^{\text {rd }}$ International Conference on Information and Communication Technologies: From Theory to Applications, available at: doi:10.1109/ictta.2008.4529987.

5. Kumar, Anup; Adlakaha, Amit and Mukherjee, Kampan (2018), "The effect of perceived security and grievance redressal on continuance intention to use M-wallets in a developing country", International Journal of Bank Marketing, Vol. 36 Issue 7, pp. 1170-1189

6. Madan, Khushbu and Yadav, Rajan (2016), "Behavioural intention to adopt mobile wallet: a developing country perspective", Journal of Indian Business Research, Vol. 8 Issue 3, pp.227-244.

7. Nizam, F.; Hwang, H. J. and Valaei, N. (2018), "Measuring the Effectiveness of E-Wallet in Malaysia", Big Data, Cloud Computing, Data Science \& Engineering Studies in Computational Intelligence, pp. 5969. 
8. Olsen, M.; Hedman, J. and Vatrapu, R. (2011), E-Wallet Properties, $10^{\text {th }}$ International Conference on Mobile Business, available at: doi:10.1109/icmb.2011.48

9. Singh, N.; Srivastava, S. and Sinha, N. (2017), "Consumer preference and satisfaction of M-wallets: A study on North Indian consumers”, International Journal of Bank Marketing, Vol. 35, Issue 6, pp. 944965.

10. Singh, Sindhu and Srivastava, R.K. (2018), "Predicting the intention to use mobile banking in India", International Journal of Bank Marketing, Vol. 36 Issue 2, pp. 357-378.

11. Sobti, Neharika (2019), "Impact of demonetisation on diffusion of mobile payment service in India: Antecedents of behavioural intention and adoption using extended UTAUT model", Journal of Advances in Management Research, available at: https://doi.org/10.1108/JAMR-09-2018-0086.

12. Taylor, Emmeline (2016), "Mobile payment technologies in retail: a review of potential benefits and risks”, International Journal of Retail \& Distribution Management, Vol. 44, Issue 2, pp. 159-177.

13. Whisker, James and Lokanan, Mark Eshwar (2019), "Anti-money laundering and counter-terrorist financing threats posed by mobile money", Journal of Money Laundering Control, Vol. 22 Issue 1, pp. 158-172.

14. Yahid, B.; Shahbahrami, A. and Nobakht, M. B. (2013), Providing security for E-wallet using E-cheque, $7^{\text {th }}$ International Conference on E-Commerce in Developing Countries: with Focus on E-Security, available at: doi:10.1109/ecdc.2013.6556725. 